\title{
Identification of the Role of Schools and New Media Against the Development of Intolerance in the World of Contemporary Education
}

\author{
Achmad Muhibin Zuhri' ${ }^{1}$ Jauharoti Alfin², Ah. Zakki Fuad ${ }^{3}$, Suhartono ${ }^{4}$ \\ amizuhri@gmail.com¹, alfin@uinsby.ac.id², ah.zakki.fuad@uinsby.ac.id ${ }^{3}$, suhartono@unesa.ac.id ${ }^{4}$ \\ State Islamic University of Sunan Ampel Surabaya ${ }^{1,2,3}$, Surabaya State University ${ }^{4}$
}

\begin{abstract}
This paper describes the problem of intolerance rooted in education. One source that is suspected of causing this behavior is the content of Islamic teachings that are biased with interests in new media. Other factors that play a role are curriculum, books, and teachers. This element of education becomes parties who intentionally or not do the indoctrination process which then leads to understanding and actions of students' intolerance at school. The emergence of new media as an instrument of indoctrination is inseparable from the use of the Internet by Laskar Jihad in the late 1990s, which succeeded in making the internet as a medium to carry out the process of indoctrination of religious understandings that lead to identity hardening that manifests in intolerance. With framing techniques, the choice of language and narrative construction are arranged to eliminate negative values. On the other hand, students make new media references as learning resources.
\end{abstract}

Keywords: Schools, New Media, Intolerance, Education.

\section{Introduction}

Expelling the seeds of violence in the education system is not easy. This indication is proven by a survey [1] which states that most teachers have a high attitude of intolerance. This condition can also be known from the fact that research which describes intolerance among students is an indication that intolerance is still flourishing [2].

The latest data released by the Center for Islamic and Community Studies (PPIM) at the Syarif Hidayatullah State Islamic University in Jakarta shows the influence of intolerance and radicalism spread to many schools and universities in Indonesia. It was taken from survey of 337 students and 264 teachers in 34 provinces. Each province is represented by one district and one city is randomly selected. The survey was conducted in the period from September 1 to October 7, 2017. The survey results are presented in the following table[3].

Table 1. Intolerance Score In Student and Teacher

\begin{tabular}{|c|l|r|}
\hline No. & \multicolumn{1}{|c|}{ Indicator } & \multicolumn{1}{|c|}{$\%$} \\
\hline 1 & Intolerance towards minority streams & 34,1 \\
\hline 2 & Intolerance for other religious groups & 48,95 \\
\hline 3 & $\begin{array}{l}\text { Do not want to associate with followers of other } \\
\text { religions because of religious doctrine }\end{array}$ & 58,5 \\
\hline 4 & Have a view of radical opinion. & \\
\hline
\end{tabular}


The results of other survey also have been released, for example, are released from Setara Institutes to see IKT (Indeks kota Toleran) or tolerant city indexes[4]. The IKT report is prepared based on tolerance practices in Indonesia, by examining how much freedom of religion / belief is guaranteed and protected through regulation and action and juxtaposing it with the reality of social behavior in the management of city diversity, especially on issues of religion / belief. The survey results released 10 cities with the lowest IKT, namely. as can be seen in table 2.

Table 2 .Cities with the Lowest Tolerance Scor
\begin{tabular}{|c|l|r|}
\hline No. & & Score \\
\hline 1 & DKI Jakarta & 2,30 \\
\hline 2 & Banda Aceh & 2,90 \\
\hline 3 & Bogor & 3,05 \\
\hline 4 & Cilegon & 3,20 \\
\hline 5 & Depok & 3,30 \\
\hline 6 & Yogyakarta & 3,40 \\
\hline 7 & Banjarmasin & 3,55 \\
\hline 8 & Makassar & 3,65 \\
\hline 9 & Padang & 3,75 \\
\hline 10 & Mataram & 3,78 \\
\hline
\end{tabular}

Some academics see a similar educational environment as the root of the problem. Plurality cannot be presented in real terms to be addressed and lived together, both teachers and students. Furthermore, the education curriculum is still normative and not comprehensive, so it fails to bring up critical pedagogy among students. Furthermore, the education curriculum is still normative and not comprehensive, so it fails to bring up critical pedagogy among students. Moreover, the textbook used is also problematic [1]. In the 2013 curriculum there are several vocabulary words that can lead to intolerant behavior of students such as "willing to defend religion", "where is there a reckless", "if our religion is insulted we are not willing", "Basoka is taken away", "finished reaching the slaughter of the clerics", and "why is the phobia of religion".

Since 2000, Islamic militant groups have made the internet as one of its media for preaching[5]. Lim looks at the fact that the internet has become a new media which is very relied upon by the Laskar Jihad group in spreading ideas and ideas of Jihad by using the Maluku conflict as the entrance. Text, sound, and video narratives that put Muslims at the expense of Muslims successfully provoked Muslims to go to jihad to Maluku.

\section{Results}

\subsection{Indoctrination Through Educational Institutions}

Since a long time, the field of education has been used to create obedient individuals through an indoctrination process[6]. Individual self-compliance arises because there is habitus deliberately constructed by the state. Dale and Apple found that schools became one of the 
modern political objects in which we can witness how certain conscience and hegemony awaken and experience destruction.

In 2015 circulated the XI grade Islamic and Character Education book that has the potential to trigger religious radicalism and hurt tolerance values[7]. In the subchapter of the book Figures of the Renewal of the Islamic World Modern period contained the thoughts of Muhammad Ibn Abdul Wahab who stated that what is permissible and must be worshiped is Allah SWT, and people who worship other than Allah SWT, have become idolatrous and may be killed. In the book, there is also a color photo written as a photo of Muhammad bin Abdul Wahab (17031787) which is a photo of Abdul Aziz bin Abullah Al Shaykh, the Saudi mufti, who is still alive today.

Even sadder is the finding of the Gerakan Pemuda (GP) Anshor (GP Anshor is Nahdlatul Ulama Youth Movement) for kindergarten books that contain elements of radicalism. Muzakki, quoting the results of GP Anshor, wrote that there were 32 sentences in the book in Depok West Java, which allegedly could direct students as readers to acts of radicalism[1]. The sentence included Sabotage, passion for Saudi, bombs, and Sahid in the field of jihad.

Indeed schools had been prepared as mini social laboratories with individuals who have Islamic thoughts and actions envisioned by hardline Islamic groups[8]. "Schools are supposed to serve, not only as places for training young students but as motors for the Islamization of society," explained Hefner.

\subsection{Use of New Media for Indoctrination of Radical Teachings}

Some contemporary studies do show the effectiveness of NIIS in using cyberspace for the community recruitment process to become part of the NIIS organization as well as the selfradicalization of the movement[7]. This fact is a reference for the government to close online media that discuss ideas, concepts, ideas, or knowledge about NIIS . Efforts made through online media are not without results. Hilmy saw an indication that the presence of NIIS had gained sympathy from the Indonesian people. The presence of 56 Indonesian citizens who have already joined the NIIS movement is proof that organizations influence Indonesia. The influence of NIIS can also be identified in jihadi organizations such as JAT and the Eastern Indonesian Mujahidin Network. Efforts made through online media are not without results. An indication that the presence of NIIS had gained sympathy from the Indonesian people. The presence of 56 Indonesian citizens who have already joined the NIIS movement is proof that organizations influence Indonesia[9]. The influence of NIIS can also be identified in jihadi organizations such as JAT and the Eastern Indonesian Mujahidin Network.

The influence of radicalism on adolescent behavior can be read in the Jihad Selfie documentary. The film was inspired by an Indonesian young man who went to jihad to Syria and Iraq because of the Facebook status (FB) of his friends taking selfies by carrying AK-47 weapons and military-style clothes[10]. The young man was not only amazed, but he saw the picture of his friend as a visualization of courage and was very fashionable to wear. He was increasingly interested in going jihad when reading narratives sent through FB Messenger about riding and shooting activities carried out during the war.

Other influences can be traced to new media used by students as a reference source. Some blogs owned by students use content as a reference for students as learning resources. At least this can be seen from the social media that is held by students often refers to the writings on the site that are considered to teach violence. Those with good scientific ability can frame one problem with a religious language so that it can be accepted if those who see the site do not perform a critical analysis process. 
In language selection, online site editors often replace words or sentences that have negative meanings such as suicide bombers that can be interpreted as suicide bombers. This word appears in paragraphs as Mujahid. To bring more positive affirmation to the text, the perpetrators are narrated as brave people because they are not afraid of US hegemony. These words are replaced in various paragraphs so that they can create a glorifying impression for the readers of the suicide bombers, especially what happened in the New York WTC building. Some Islamic media online such as Arrahmah refer to it as holy warriors. Intentional errors by the owners of this new media grow and are reproduced continuously. Tragically students then read the understanding, and they guarantee it because it is not a match discourse.

\section{Conclusion}

Some new media can be a trigger for the problem of intolerance which lately has increasingly emerged in the practice of education in Indonesia. The characteristics of the current generation that cannot be separated from the world of the internet in searching for reading material and other learning resources are easy targets for providers of religious content in new media that are not slightly filled with hardline Islam. With framing and the construction of narratives that subtly lead to intolerant teachings results in many teachers and students who directly or indirectly dictated their minds to think and act intolerantly.

\section{References}

[1] A. Muzakki, “Ancaman Pendidikan Kewarganegaraan,” Kompas, Jakarta.2018

[2] F. Wajidi and A. Bagir, "Kaum Muda dan Pluralisme Kewargaan," in Plur. Kewargaan Arah Baru, 2011.

[3] A. M. I. T. Muthahhari, "Survei (UIN)Jakarta: Intoleransi Tumbuh di Banyak Sekolah dan Kampus," tirto.id. Tirto.id, 2017.

[4] M. S. H. S. Gerintya, "Benarkah Intoleransi Antar-Umat Beragama Meningkat," tirto.id. Tirto.id, 2018.

[5] M. Lim, "Cyber-Civic Space in Indonesia: From Panopticon to Pandemonium," Int. Dev. Plan, 2002.

[6] M. W. Apple, “Common Curriculum And State Control,” Cult. Polit. Educ., vol. 2, no. 2, pp. 110.1982

[7] A. Azra, "Waspadai Paham Radikal," Kompas, Jakarta, vol. 7, 2015.

[8] R. W. Hefner, Making Modern Muslims: The Politics of Islamic Education in Southeast Asia. University of Hawaii Press, 2009.

[9] M. Hilmy, "Genealogi dan Pengaruh Ideologi Jihadisme Negara Islam Iraq dan Suriah (NIIS) di Indonesia," vol. 4, no. 2, pp. 404-428, 2014.

[10] H. I. Noor, "Melacak Alasan Orang Terpincut ISIS via \& quot; Jihad Selfie \& quot," Kompas.com, 2015. 